\title{
Rising competitive authoritarianism in Turkey
}

\section{Berk Esen \& Sebnem Gumuscu}

To cite this article: Berk Esen \& Sebnem Gumuscu (2016) Rising competitive authoritarianism in Turkey, Third World Quarterly, 37:9, 1581-1606, DOI: 10.1080/01436597.2015.1135732

To link to this article: https://doi.org/10.1080/01436597.2015.1135732

央 Published online: 19 Feb 2016.

Submit your article to this journal 저

LII Article views: 4498

Q View related articles $\sqsubset$

View Crossmark data

Citing articles: 31 View citing articles ๔ 


\title{
Rising competitive authoritarianism in Turkey
}

\author{
Berk Esen $^{\mathrm{a}}$ and Sebnem Gumuscu ${ }^{\mathrm{b}}$

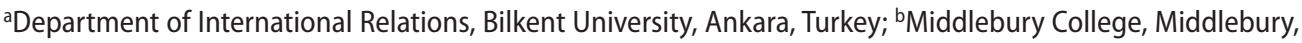 \\ VT, USA
}

\begin{abstract}
Since the Justice and Development Party (AKP) came to power in 2002 Turkey has undergone double regime transitions. First, tutelary democracy ended; second, a competitive authoritarian regime has risen in its stead. We substantiate this assertion with specific and detailed evidence from 2015 election cycles, as well as from broader trends in Turkish politics. This evidence indeed confirms that elections are no longer fair; civil liberties are being systematically violated; and the playing field is highly skewed in favour of the ruling AKP. The June 2015 election results and their aftermath further confirm that Turkey has evolved into a competitive authoritarian regime.
\end{abstract}

\section{ARTICLE HISTORY}

Received 28 October 2015

Accepted 21 December 2015

\section{KEYWORDS}

Competitive authoritarianism Turkey

AKP

elections

democracy

democratic backsliding authoritarian retreat

On 6 September 2015 the Kurdish separatist group PKK attacked two armoured military vehicles in Daglica, a provincial town near Turkey's border with Iran and Iraq. This was the deadliest terrorist attack - 17 dead and several others injured - since the launching of 'the peace process' in 2012. Announcing the incident on TV, President Recep Tayyip Erdogan suggested that such attacks would not have occurred if voters had given 400 MPs to 'one political party' in the June 2015 election. ${ }^{1}$ After 13 years of single-party rule, the Justice and Development Party (AKP) founded by Erdogan had indeed lost its parliamentary majority in the June 2015 election and was forced to lead coalition talks with other parties. The national daily Hurriyet soon broadcast Erdogan's words from its website, thereby reinforcing the view widely shared by those in the opposition that the president had escalated the conflict with the PKK to win back conservative voters in the snap election scheduled for November 2015. Disturbed by his implied association with post-election violence, Erdogan protested to the newspaper. ${ }^{2}$ A few hours later a group of AKP vigilantes, led by the leader of the AKP's youth branch and Istanbul MP, attacked Hurriyet's headquarters in Istanbul. ${ }^{3}$ The police stood aside during the incident; ${ }^{4}$ luckily no one was injured. This contentious day captured quite accurately the current condition of Turkish politics on the eve of the snap election. The AKP's desire to hang on to power despite its electoral defeat accompanied a dramatic rise in political violence and extra-parliamentary opposition, which, in turn, increased government pressure on dissent, including censorship in the media and implicit endorsement of violent attacks against the opposition by AKP supporters. 
In this paper we argue that Turkey under the AKP government has devolved from a tutelary democracy into a competitive authoritarian regime. We also claim that Turkey is part of a broader trend of global authoritarian retreat observed in the weakening of political institutions and the erosion of rule of law by leaders who had initially come to power through the ballot box. ${ }^{5}$ Indeed, scholars have acknowledged the AKP government's limiting civil liberties and increasing concentration of power in Erdogan's hands, ${ }^{6}$ yet few have noted Turkey's retreat into an authoritarian model under AKP rule. ${ }^{7}$

Our aim in this paper is twofold. First, we engage in this debate by demonstrating that Turkey no longer satisfies even the minimal requirements of democracy. ${ }^{8}$ Second, we aim to carve out analytical space to study other cases of democratic backsliding, such as Thailand and Hungary, through a detailed analysis of Turkey, a critical yet under-studied case in the democratisation literature.

In what follows we first discuss the reasons why 'competitive authoritarianism' better captures Turkey's regime trajectory than types of defective democracy. We then continue with a brief discussion of the end of tutelary democracy in Turkey. This discussion is critical, since tutelary powers and competitive authoritarianism are mutually exclusive, as proposed by Levitsky and Way. ${ }^{9}$ In section three we substantiate competitive authoritarianism in Turkey with a particular focus on the June and November 2015 elections, to demonstrate how the playing field is skewed in favour of the AKP. Specifically we discuss the ways in which the party has abused its control over the state-owned media and regulatory agencies; used legal actions to harass critics and reward supporters in the media and civil society; employed large-scale repression of opposition groups through the securitisation of dissent; and relied on widespread use of public resources and abuse of public-policy instruments to gain access to greater private finance for the party. We conclude with a discussion of the November 2015 elections.

\section{Why competitive authoritarianism?}

With the end of the Cold War there has been an increase in competitive authoritarian (CA) regimes. ${ }^{10}$ Unlike fully fledged autocracies, CA regimes hold regular elections devoid of fraud as the primary means for attaining power. But the government's partisan use of state institutions makes it unlikely for the opposition to defeat the incumbent, thereby rendering such cases undemocratic. As Levitsky and Way succinctly put it, 'such regimes are competitive in that opposition parties use democratic institutions to contest seriously for power, but they are not democratic because the playing field is heavily skewed in favor of incumbents.' ${ }^{11}$ Put differently, competition in such cases is real but unfair. While incumbency carries a certain degree of advantage even in liberal democracies, CA regimes stand out by undermining the opposition's capacity to organise and compete in elections. In these cases the government appropriates state resources for partisan distribution and packs state institutions systematically with its loyalists. It also controls the media to limit the opposition's access to voters and weaken its political campaigns. Lastly, government critics are threatened, harassed and, occasionally, prosecuted. As a result of the government's skewed access to resources and institutions, the opposition faces an uneven playing field against the incumbent party.

This paper asserts that, under the rule of the AKP, Turkey has devolved into such a competitive authoritarian regime, instead of consolidating its democracy (or remaining a type of defective democracy for that matter). Accordingly, the AKP, which first came to power in 
2002, has captured state institutions through its electoral victories and used its power to establish hegemony over Turkish society. Under its dominance the opposition has continued to participate in national and local elections but faces an uphill battle in competing against the ruling party.

We suggest that competitive authoritarianism better captures the complexity of ongoing regime change in Turkey than do several types of defective democracy (eg delegative, electoral, majoritarian, plebiscitarian or illiberal). ${ }^{12}$ First, recent trends in Turkey not only demonstrate a lack of democratic consolidation but they also denote a clear case of authoritarian retreat, as we show below. Second, these subtypes fail to depict the nature of political contestation in Turkey, where elections function as key political institutions and permit competition, albeit on a highly uneven playing field. As such, the fairness of elections is increasingly contested; civil liberties are systematically violated; and the playing field is highly skewed in favour of the incumbent AKP. The concepts of illiberal or electoral democracy are attuned to violations of civil liberties yet they fail to assess the implications of a skewed playing field for free and fair elections, which constitute the essence of even defective democracies. Most scholars of Turkish politics continue to classify Turkey as majoritarian or illiberal democracy with heavy Islamist undertones, with occasional references to a trend towards electoral authoritarianism. ${ }^{13}$ Here, we provide ample evidence to demonstrate how the AKP government's policies have obstructed 'the freedom, fairness, inclusiveness, and meaningfulness of elections' which, according to Diamond, distinguishes electoral democracies from electoral authoritarianism. ${ }^{14}$

Third, these concepts differ in their implications. Subtypes of democracy often carry a bias in favour of democratic transition and therefore fail to capture the distinctive logic of authoritarian politics. By way of contrast, the concept of competitive authoritarianism allows us to assess the role of formal and informal rules in cases where democratic institutions coexist with authoritarian incumbents. ${ }^{15}$ As such, competitive authoritarianism takes into account aspects of a political regime other than its electoral system, thereby allowing us to focus on different aspects of the AKP's regime.

Finally, competitive authoritarianism better depicts the empirical reality in Turkey compared with subtypes of democracy. For instance, Tas asserts that Turkey has transformed into a delegative democracy under the AKP, one where Erdogan acts as an embodiment of national interest with his anti-political stature. ${ }^{16} \mathrm{~A}$ closer look at Erdogan's discourse, however, reveals unprecedented attempts to polarise and politicise Turkish society. ${ }^{17}$ That Erdogan has consistently violated the norms of impartiality in favour of the AKP since his ascendance to the presidency is another challenge for the concept of delegative democracy. Put differently, the uneven playing field, as we discuss in detail below, implies that the Turkish case lacks not only horizontal but also vertical accountability as a result of the absence of fair elections.

In fact, O'Donnell coined the term 'delegative democracy' based on his political observations of Argentina, Brazil and Peru, countries that were governed by a presidential system and led by charismatic politicians. ${ }^{18}$ In the existing parliamentary system in Turkey, however, no leader can claim power without being backed by a strong political party. Thus, up until the 2014 presidential elections Erdogan exercised power as the leader of a dominant party. His election as president in August 2014 with the popular vote has not altered this reality, since the current constitution in Turkey vests executive power in the hands of the prime minister. The de facto situation that Erdogan created after his election - acting as the head of the executive - has ensued because of the AKP's control over parliament and his 
uncontested power in the party. ${ }^{19}$ Erdogan's power, in other words, depends on the AKP's continued electoral success. ${ }^{20}$

Finally, the classification of the Turkish case as a delegative democracy obscures the qualitative difference between the AKP's dominant party regime and the centre-right governments of the post-1980 period which, though corrupt and violating civil liberties, fell short of dominating and monopolising the political arena.

Recent political developments in Turkey offer an invaluable opportunity to generate novel theories on democratisation and authoritarian reversals. Given its history of multiparty politics, mid-level income and accession talks with the EU, Turkey - together with Thailand and Hungary - has been one of the major democratic under-performers of the past decade. ${ }^{21}$ After all, the country scores high on structural factors, which scholars of comparative politics have identified as necessary for democratic consolidation; Turkey neither faces a resource curse nor has a weak state - two conditions that have thwarted democratic consolidation in other parts of the global South. After the 2001 financial crisis the Turkish economy grew rapidly and the country's level of economic development is higher than that of many countries which have consolidated their democratic regimes in the past two decades. By contrast, despite experiencing its first democratic turnover in 1950, Turkey has failed to consolidate its democratic regime.

\section{The end of tutelary democracy in Turkey}

The AKP rose to power in an unconsolidated democracy where the military's legal-institutional role amounted to a virtual veto power over elected officials. ${ }^{22}$ The judiciary also acted as a veto-player in the democratic system, wielding tutelary powers. ${ }^{23}$ In its tenure since 2002, however, the AKP has empowered formerly disenfranchised social groups of predominantly Islamic and Kurdish identity, and curtailed the power of the veto-players in Turkish politics. Specifically the AKP has undercut the military's political power by opening up a greater space for elected officials in decision making through a series of reforms and has redesigned the higher courts via judicial reforms enacted through a constitutional referendum.

With its strong electoral mandate, the AKP reduced the military's influence in politics (1) by implementing legal reforms that reduced the institutional power of the military in decision making; (2) through the political de-legitimisation of the military's extra-legal interventions in politics; and (3) by criminalising such interventions. These institutional reforms entailed a reduction in the power of the military through a set of alterations: the number of civilian members in the National Security Council (MGK) increased; ${ }^{24}$ the frequency of MGK meetings was reduced, while the decisions made by the council were downgraded to the level of recommendations for the government, recommendations that did not require the Council's supervision over their implementation; the composition of the boards of the Council of Higher Education (YOK) and the Radio and Television Supreme Council (RTUK) were altered by taking out the seat reserved for military officers; and, lastly, the EMASYA protocol, which allowed the military authorities to bypass civilian authorities in responding to social incidents, was annulled. ${ }^{25}$

If these reforms limited the scope of the military's legal-institutional influence in politics, a critical set of developments after 2007 rendered the military's extra-legal intervention politically illegitimate. The government dismissed the armed forces' attempt to intervene in the presidential elections of 2007 as unacceptable by underlining the primacy of democratic 
procedures. Subsequently, the AKP took steps to criminalise military involvement in politics through a set of court cases that began during the party's second term in office (2007-11). In the 'Ergenekon' and 'Sledgehammer' cases, hundreds of retired and on-duty high-ranking military personnel were brought before the courts to answer allegations of conspiring to overthrow the elected AKP government. ${ }^{26}$ Among these officers were the former chief of general staff, Ilker Basbug, and several former commanding officers of the army. These court cases signified that the military was no longer untouchable nor were they above censure by the elected civilian government. ${ }^{27}$ These developments brought about a dramatic change in civil-military relations in Turkey by reducing the influence of military officers over politics. ${ }^{28}$

At the same time the AKP garnered success as the representative of the disenfranchised the social groups of explicitly Islamic or Kurdish identity formerly sidelined under the Kemalist regime established in 1923 - expanding the social basis for democracy and increasing the legitimacy of the democratic system in Turkey. Attesting to this fact is the decline in support for Shari'a and an Islamic regime among the Islamic constituencies, who felt included and represented in the democratic system after the AKP came to power, from $21 \%$ in 1999 to $9 \%$ in 2007. ${ }^{29}$ Similarly the AKP altered the Kurdish policy of its predecessors and opened up space for the expression of Kurdish identity in the public realm. ${ }^{30}$ Indeed, despite its shortcomings and tumultuous nature, the AKP also initiated a peace process with the Kurdish insurgency to resolve the protracted conflict in the country.

Despite these critical steps, the AKP oscillated between liberal and majoritarian understandings of democracy. ${ }^{31}$ First, the party's desire to dictate its terms on Kurdish and Alevi groups, instead of engaging in deliberation, generated doubts about the party's attachment to liberal democratic principles. ${ }^{32}$ Second, the process of civilianisation of politics came at a high cost, as the AKP's undemocratic and illiberal measures in highly politicised trials against members of the armed forces eroded rule of law as well as fundamental human rights. For instance, defendants of both the 'Ergenekon' and 'Sledgehammer' cases witnessed a violation of their fundamental rights in due process. As the recent conflict between the AKP government and the Gulen movement has revealed, ${ }^{33}$ the party apparently utilised courts under the influence of the Gulenists to subdue and intimidate the rank and file in the armed forces, often through fabricated evidence and violation of due process. ${ }^{34}$ The subordination of the judiciary, which started with these trials, did indeed come full circle when the AKP government passed a constitutional referendum in 2010 designing the higher courts and Supreme Council of Judges and Prosecutors. ${ }^{35}$ In short, by the end of 2010 the AKP had already pacified most of the veto-players in the system and ended the era of tutelary democracy in Turkey.

\section{Competitive authoritarianism in the making}

The end of tutelary democracy in Turkey did not result in democratic consolidation in the country, as hoped by students of Turkish politics. Instead, the popularly elected AKP government took an authoritarian turn. The AKP used its electoral strength - based on a crossclass coalition across both urban and rural areas - to dominate political institutions and exploit state resources in a partisan manner to block the opposition's chances of winning an election. While falling short of outright repression, these measures have tilted the playing field against the opposition parties, thereby allowing the AKP to stay in power without the need to resort to massive electoral fraud and repression. ${ }^{36}$ These developments meant that Turkey now fulfilled the criteria of competitive authoritarianism rather than of a defective 
democracy. That is, '[Turkey] is not a full authoritarian regime; there is universal suffrage; the authority of elected officials are not restricted by unelected tutelary powers; and at least one of the following criteria are met: 1) unfair elections, 2) violation of civil liberties, and 3) uneven playing field. ${ }^{37}$ We have already addressed the disestablishment of tutelary powers under the AKP. We now turn to the three definitive criteria of competitive authoritarianism observed in Turkey.

\section{Unfair elections}

Levitsky and Way suggest that elections are unfair in cases where'1) at least one major candidate is barred for political reasons, 2) centrally coordinated and tolerated electoral abuse is asserted by credible independent sources (serious partisan manipulation of voter rolls, large-scale voter intimidation, ballot-box stuffing, falsification of results), 3) significant formal or informal impediments prevent the opposition from campaigning on equal footing and 4) the playing field is uneven' ${ }^{38}$ Although the authors claim at least one of the four is sufficient to designate a regime $C A$, Turkey exhibits multiple such indicators.

To start with, no major candidate is barred for political reasons under AKP rule. Neither is there sufficient evidence showing the presence of centrally coordinated and tolerated electoral abuse. That said, the electoral process has come under greater scrutiny in recent years. After the 2010 referendum, the composition of the Supreme Election Council (YSK) - whose members are elected by the Supreme Court and the Council of State - changed in a way that increased the government's influence. ${ }^{39}$ Furthermore, allegations of electoral abuse during vote counting in the March 2014 local elections reached unprecedented levels, particularly in closely contested areas like Ankara and Antalya, won by the AKP. ${ }^{40}$ The YSK's refusal to answer these allegations, coupled with high-level government officials'visits to the election centres in Ankara and Antalya during the vote-counting process, ${ }^{41}$ further increased doubts as to the fairness of elections in Turkey. ${ }^{42}$

Before the June 2015 elections the opposition politicians and media also raised concerns about Turkey's use of Computer Supported Centralized Voter Roll System software, which they argued could be open to electronic manipulation. ${ }^{43}$ The absence of routine election observation by international actors further intensified concerns over widespread vote rigging. Largely in response to these fears, a new civil society group - Oy ve Otesi - spearheaded a public campaign to monitor elections. Despite the pro-AKP media's attempts to undermine the credibility of this civil society initiative before the June and November 2015 elections, ${ }^{44}$ Oy ve Otesi managed to monitor $76 \%$ of the ballot boxes in November. After the elections the organisation reported only a $0.02 \%$ mismatch between its unofficial count and the election results released by the YSK in the polls monitored. ${ }^{45}$

As this discussion shows, there is no systematic electoral manipulation in Turkey. However, the absence of rigged elections does not necessarily mean that elections are fair. The election laws in Turkey do not allow for parties to campaign for extended periods. Needless to say, this created a huge advantage for the ruling AKP, which in effect began to campaign unofficially at public events. By contrast, this short period was not enough for the opposition - already excluded from much of the media and with limited resources, as discussed below - to carry its message to new voters. Furthermore, the opposition was denied competition on an equal footing. In several instances when an opposition rally coincided with 
a government-sponsored event (especially those attended by the prime minister or the president) at the same place, the opposition party was asked to reschedule the event. ${ }^{46}$

More disconcerting with regard to the fairness of the elections have been growing attacks on opposition activists, particularly the pro-Kurdish Peoples' Democratic Party (HDP) in the course of the election campaigns of June and November. On 18 May 2015 two bombs detonated in the HDP's provincial headquarters in Mersin and Adana. Against this backdrop, there were two serious attacks at HDP rallies during the closing week of the campaign cycle in June. On 4 June a large group attacked an HDP pre-election rally, injuring 38 people, while the next day two explosions at the HDP Diyarbakir rally killed three people and injured over 100. A Human Rights Association (IHD) report reveals that between March 2015 and June 2015 there were 176 attacks on the HDP, killing five people and injuring $522 .{ }^{47}$ The fact that the AKP government proved to be slow in reacting to these events and bringing the perpetrators to justice failed to deter further attacks. ${ }^{48}$

A month after the June elections a group of HDP activists was targeted by a suicide bombing in the southeastern town of Suruc, where 33 were killed and over 100 were injured. This attack marked a return to violence in Turkey's Kurdish question, as the two sides mutually ended the ceasefire, in effect since 2013. In this new cycle of violence Turkish security forces failed to prevent mob attacks targeting the HDP offices as well as pro-HDP businesses. Besides these informal impediments, the HDP was also subject to formal impediments, as the security forces detained several party members weeks before the November elections in four different cities using the escalating conflict with the PKK as a pretext. ${ }^{49}$ In October 2015 HDP activists were once again the target of suicide bombings in a peace rally in Ankara, with 102 dead and 400 injured. ${ }^{50}$ As a result of increasing security concerns after attacks in Ankara, the HDP leaders decided to call off their rallies before the November elections. ${ }^{51}$ These formal and informal impediments severely curtailed the human resources and destroyed the infrastructure of the HDP.

\section{Uneven playing field}

Three major indicators compose an uneven playing field: (1) politicised state institutions; (2) uneven access to media; and (3) uneven access to resources. It is possible to observe all three indicators in the case of Turkey; these not only skewed the playing field in favour of the AKP but also eroded electoral fairness.

\section{Politicised state institutions}

The fusion of the state and the party under the AKP's dominance has generated deeply politicised state institutions. After his election as the new president, Erdogan refused to abide by his constitutionally neutral status and held rallies across the country during the 2015 campaign under the pretext of public openings of construction projects. The Supreme Electoral Council rejected numerous formal complaints from the opposition parties, ${ }^{52}$ thereby allowing Erdogan to complement Prime Minister Davutoglu's campaign schedule. ${ }^{53}$ Moreover, provincial governors (an unelected position in the Turkish context) distributed goods to voters on behalf of the AKP government, campaigned for the government informally and promoted the ruling party during official functions. ${ }^{54}$ This support left opposition activists with the impression that they were competing not only against the ruling party but also against the entire state apparatus. Finally, the AKP took advantage of its penetration of the 
bureaucracy to access personal information on specific segments of the electorate, such as first-time voters and expatriates, and sent them personalised letters before the June and November elections, ${ }^{55}$ in what some claimed as a violation of privacy according to both Turkish and European law. ${ }^{56}$

Similarly, the AKP government mobilised state employees for its electoral campaign and to undermine the opposition's efforts. The media have documented numerous cases of public employees removing campaign posters set up by the opposition parties. ${ }^{57}$ In many instances the police confiscated anti-government propaganda material. Similarly, in May 2015, security forces blocked the entry of a CHP election truck into a public square in Erzurum on the pretext of 'damage to a historical place'. Over the following days, despite a favourable ruling from the local election board and pleas from the CHP Secretary General, Gursel Tekin, the police refused to budge, leaving the party's campaign workers with no option but to campaign in a less crowded area. ${ }^{58}$ Moreover, local courts in Kirikkale and Duzce, among others, decided to remove MHP banners that accused Erdogan of embezzlement before the June elections. ${ }^{59}$

Consequently, the opposition parties were forced to campaign in their electoral strongholds, while municipalities controlled by the AKP were, for the most part, off limits. Some AKP mayors pressured local patrons into not renting their salons and stores to other political parties for their campaign events. In Rize, for instance, the AKP-run municipality cited a lack of legal documents as a pretext to close a wedding salon that had been rented out by the MHP as its campaign bureau. ${ }^{60}$

\section{Uneven media access}

In its 13 years in power the AKP spent considerable effort streamlining the mainstream media while building a pro-government media bloc, as we discuss in greater detail below. These efforts proved particularly successful in creating an uneven political playing field. After the 2015 elections, for instance, the Organisation for Security and Cooperation in Europe (OSCE) released a report that highlighted the AKP's uneven access to media via public and private outlets. In particular, the state-owned Turkish Radio and Television (TRT) station closely controlled by the ruling party has been a bastion of government propaganda. ${ }^{61}$ During the June 2015 campaign TRT allocated $46 \%$ of its airtime to the ruling AKP, not counting the airtime reserved for President Erdogan, who actively campaigned for the AKP during elections. ${ }^{62}$ This trend continued unabated during the campaign for the November 2015 election. ${ }^{63}$

Private media outlets with close ties to the AKP, such as NTV and ATV, also undermined the opposition's access to media by allocating one third of their live coverage to the AKP leaders. CNN Turk, of the Dogan Medya group, was the only exception, providing greater access to the opposition parties, the CHP and the HDP; ${ }^{64}$ it thus became the target of pro-AKP media and AKP supporters, which openly threatened and eventually attacked the group's newspaper, Hurriyet, and its columnist Ahmet Hakan. ${ }^{65}$

The picture is no different when it comes to the parties' ability to finance political ads on different broadcasting stations. Needless to say, the ruling party had the lion's share of political ads in the campaign period, followed by the main opposition party, the CHP, with a modest $19 \%$. This difference is partly a reflection of divergence in the parties' resources and partly a result of their parties' politicised access to different stations. For instance, the AKP was the only party with access to political ads on ATV, owned by a pro-AKP entrepreneur. Likewise, it was the AKP that managed to buy $91 \%$ of all the political ads shown on 
state-run TRT. ${ }^{66}$ The same TRT refused to air CHP's campaign ad because it 'directly targeted the ruling party'.67

\section{Uneven access to resources}

The AKP government also politicised public resources to skew the playing field against the opposition. In the electoral arena this created an enormous advantage for the ruling party, which outspent its rivals, leading to unfair competition. The OSCE observation reports on the 2014 presidential and 2015 general elections document that Erdogan's campaign appearances were often combined with official events to legitimise the use of public funds for their financing. On 30 May 2015, for instance, the Istanbul Metropolitan Municipality organised a public event (to which students and teachers from public schools were invited) to commemorate the Ottoman conquest of Istanbul, which turned into an AKP campaign rally. ${ }^{68}$ In their speeches Prime Minister Davutoglu and President Erdogan both attacked the opposition. These public events allowed the ruling party to conduct political propaganda and gain visibility at taxpayer's expense. During the 2015 campaign, moreover, Davutoglu used state resources to travel across the country to attend rallies in several provinces, while the opposition leaders could only afford a limited travel budget from their party funds. More importantly, both Erdogan and Davutoglu have access to discretionary funds, which are exempt from bureaucratic oversight. Indeed, both Erdogan and Davutoglu overspent these funds in the course of campaign periods, ${ }^{69}$ reflecting a broader trend under the AKP rule ${ }^{70}$, confirming the CHP's concerns about the use of state funds for campaign finance. ${ }^{71}$

The AKP's access to public resources and authority also delivered greater access to private resources in the form of donations and campaign contributions. Businessmen with close ties to the ruling party contributed to party efforts in a number of ways. For instance, during the 2014 presidential campaign, Erdogan had a huge and clear advantage in donations over his two rivals. ${ }^{72}$ In some cases businessmen make in-kind donations to local party officials to be distributed to voters. For instance, just after the outbreak of the Gezi protests, Zorlu Holding reportedly sent 40,000 food packages - worth in total some two million lira - to the AKP's Istanbul branch. ${ }^{73}$ In others, businessmen seeking public contracts make donations to the AKP chapters, employ party members in their companies, ${ }^{74}$ and mobilise their employees to attend AKP rallies. ${ }^{75}$

Alternatively, they make sizable donations to pro-AKP charities. These charities not only transfer resources provided by the business actors to the urban poor within the AKP constituency, but they also circulate funds from businessmen to the party elite. The cases of Deniz Feneri and TURGEV are particularly revealing. Deniz Feneri is a charity based in Turkey with branches in Germany. In 2008 the German authorities revealed that Deniz Feneri eV collected $€ 41$ million for earthquake relief in Indonesia but sent $€ 16$ million of this to Turkey rather than to the intended recipients. The German courts ruled that Deniz Feneri eV was guilty of embezzlement and had close connections with the AKP elite. These charges were dismissed in Turkey because of insufficient evidence and statutory limitation soon after the prosecutors in the case were replaced by the Supreme Council of Judges and Prosecutors. ${ }^{76}$

TURGEV, on the other hand, is a foundation established by Erdogan and his family members. The recordings leaked in 2013 as part of the graft probe revealed the links between pro-AKP businessmen and TURGEV. ${ }^{77}$ Not surprisingly, most of those Turkish businessmen were predominantly recipients of government contracts. ${ }^{78}$ The Speaker of the government, 
Bulent Arinc, in response to a CHP MP's inquiry about the foundation, confirmed in 2014 that TURGEV had collected millions of dollars in donations. ${ }^{79}$

Last but not least, new networks have emerged in civil society to provide political support for the AKP. The Sivil Dayanisma Platformu (Civil Solidarity Platform) is established as a network of civil society organisations with close ties to the ruling party. The SDP lobbied in favour of Erdogan soon after the eruption of the corruption scandal in December 2013. As part of this effort, the platform placed ads supporting Erdogan in 4000 different locations in Istanbul just before the local elections in March 2014. The chairman of the platform stated that the costs were covered by those businessmen who routinely support the pro-AKP foundations and associations. ${ }^{80}$

\section{Violation of civil liberties}

Violation of civil liberties has taken a systematic form under the AKP government, which has not only created an uneven playing field but has also securitised dissent. More specifically frequent harassment of independent media, restrictions on freedom of political association and speech, and suppression of opposition figures or other government critics have become ordinary features of politics in Turkey.

\section{Media}

The AKP's pressure on media has constituted a major pillar of its rule since 2002. Besides creating an AKP-friendly media, the government has also disciplined the mainstream media via intimidation, mass firings and imprisonment of journalists, and buying off media moguls. ${ }^{81}$ In other words, using its access to state resources, the party has rewarded its supporters and punished or isolated its enemies. Thanks to the structure of the Turkish media sector, which is composed of companies owned by large holdings with interests in other sectors, such measures have been largely effective. ${ }^{82}$

To redesign the media sector, the AKP put political and financial pressure on the critical media outlets. ${ }^{83}$ Dogan Media, a major media conglomerate in Turkey, has been the focus of extensive political pressure, for example. In 2009, after newspapers affiliated with the Dogan Media covered the Deniz Feneri case in Germany, the national broadcasting authority (RTUK) ordered the closure of 11 unlicensed Dogan broadcasting stations and the tax agency fined the company a total of US\$3 billion for tax evasion, what many referred to as a political decision. The European Commission's progress reports in 2009 and 2010 asserted that these fines hurt the freedom of the press in Turkey. ${ }^{84}$ In response to these measures, Dogan Media sold Milliyet and Vatan, two widely circulated and well-established newspapers, to businessmen with close ties to the AKP government. ${ }^{85}$ The pressure on Dogan Media has not receded, however, and the company remained an important political target for the AKP and its supporters, as we have already discussed above.

A more recent target of the AKP government has been the Gulen movement, which is currently subject to criminal investigation and also under pressure over its media operations. Media outlets affiliated with Fethullah Gulen were raided by security forces, ending in the detention of executives, journalists and media workers. ${ }^{86}$ More recently the AKP silenced Gulen's broadcasting stations in October 2015, when Turksat, Digiturk and TTNET denied access to these networks in their platforms, ${ }^{87}$ on the orders of Erdogan's chief aides. ${ }^{88}$ 
The AKP government has also established a number of informal institutions to discipline the mainstream media. One of these institutions involved the appointment of pro-AKP managers and journalists in major TV stations and newspapers. These figures served as the representatives of the government in their respective media companies, supervised the internal operations of these stations, and altered news content in line with the orders coming from the prime minister's office. ${ }^{89}$ Through these intermediaries the government managed to limit the air time that politicians from the opposition parties get and gain disproportionate access to both state and private TV channels. ${ }^{90}$

Erdogan also directly and publicly attacked critical journalists, who were subsequently fired by their bosses, fearing government reprisal. ${ }^{91}$ Those journalists who refused to back down in the face of intimidation were purged in mass firings. One major wave struck soon after the AKP had won its third term in office in June 2011. Another wave struck when the Turkish air force bombed and killed 34 unarmed cross-border petty smugglers mistaken for Kurdish insurgents in December 2011. A third major wave hit with the Gezi Park protests in the summer of 2013, when the mainstream media refrained from reporting on one of the most wide-scale protests in Turkish history. One hundred and forty-three journalists were either fired or forced to resign in 2013 alone. Mass firings continued to be a critical instrument of censorship in 2014, with 339 journalists losing their jobs. ${ }^{92}$

In addition to political and financial pressure on the media, the government has applied legal pressure to journalists through defamation and criminal lawsuits. Between 2003 and 2015 '63 journalists have been sentenced to a total of 32 years in prison, with collective fines of 128,000 USD', excluding the fines charged to newspapers and journalists. ${ }^{93}$ The AKP has also taken further steps to securitise journalistic activity. A new anti-terror law in 2006 allowed for the imprisonment of journalists for up to three years for the dissemination of statements and propaganda by 'terrorist organisations'. The law first affected pro-Kurdish journalists; under the auspices of the anti-terror law prosecutors detained nearly 150 journalists in 2010 , a total of 33 people were sentenced to more than 365 years in prison and received fines of up to $\$ 35,000 .{ }^{94}$ By April 2012 more than 100 journalists had been detained, most of whom were tried on alleged violations of the anti-terror law.

These practices had already established a deep culture of censorship and self-censorship by 2010. A survey conducted among high-ranking representatives of mainstream media indicates the extent to which journalists, editors and editors-in-chief are subject to pressure from the government. ${ }^{95}$ Ninety-six per cent of the respondents reported that the AKP government was the most important actor in determining the news content, while $91 \%$ agreed that they did not report important stories because of government pressure. A Freedom House special report on press freedom in Turkey released in 2014 confirms these findings of pervasive self-censorship through interviews with editors in the mainstream media outlets. ${ }^{96}$

In the meantime media blackout has become an instrument frequently used by the government to reinforce the already existing trends of censorship. Reporting on a number of events and developments the AKP deemed controversial became impossible with these blackouts. For instance, 4091 investigations have been launched against journalists for breaches of confidentiality of investigations or for attempts to influence a fair trial through their reporting on the Ergenekon case. ${ }^{97}$ Similarly media blackouts were used at the discretion of the AKP government to prevent coverage of the Deniz Feneri case, ${ }^{98}$ the Uludere bombing (December 2011), the Reyhanli attack (May 2013), the December 2013 graft probe, the hostage crisis at the Turkish consulate in Mosul (Summer 2014), the recent 


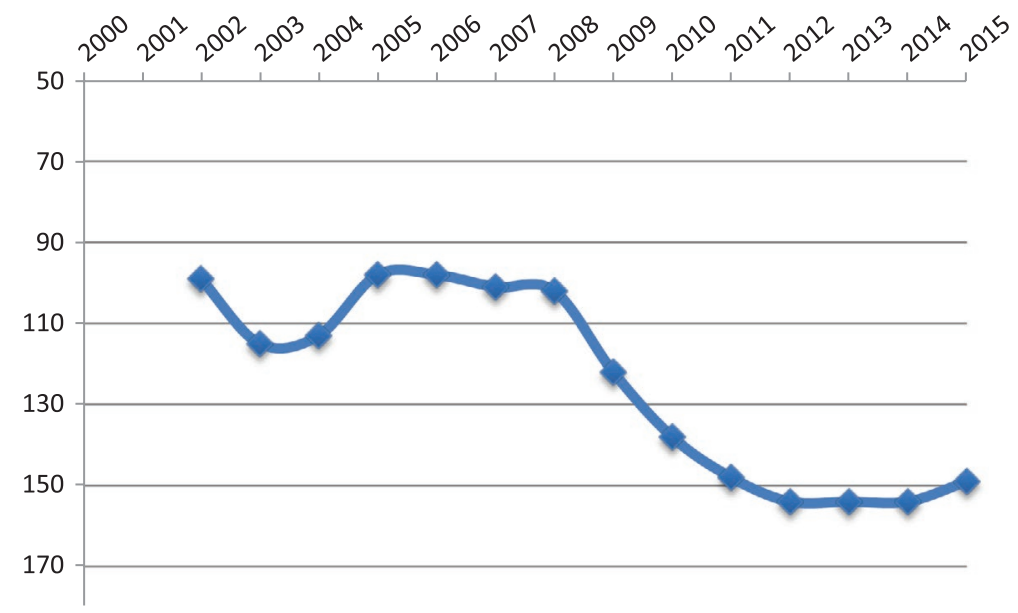

Figure 1. Press freedom in Turkey. Source: Compiled from Reporters without Borders, World Press Freedom Index, 2002-2015, https://index.rsf.org/\#!/.

clashes between Kurdish resistance and ISIS in Kobane (Autumn 2014), bombings at the HDP rally in Diyarbakir during the June 2015 election campaign, and suicide bombings in Suruc and Ankara in July and October 2015, respectively. ${ }^{99}$

Not surprisingly, press freedom in Turkey has quickly deteriorated over the past decade. In 2002 Turkey ranked 99 in the press freedom index released by Reporters without Borders, but this has declined to 154 in 2014, as Figure 1 indicates. ${ }^{100}$ Confirming this trend, Freedom House changed Turkey's press freedom status to 'not free' in 2014.

\section{Freedom of expression}

The AKP government's pressure has also penetrated the lives of ordinary citizens, substantially curtailing their freedom of expression. Restrictions on social media constitute a major roll-back of freedom of expression in Turkey. A striking attempt to erode civil liberties came when the AKP government, through its regulatory agencies, blocked YouTube and Twitter following the corruption scandal of December 2013. Both these platforms were banned until the March 2014 local elections, depriving citizens of their freedom of expression and information during these major crises.

Moreover, the government's surveillance has extended beyond social media and culminated in wide-scale censorship over the internet. ${ }^{101}$ In February 2014 the AKP government amended the Internet Law (Law No 5651) to expand the government-controlled Telecommunications Authority's (TIB) jurisdiction over websites and to curtail judicial oversight over its decisions. ${ }^{102} \mathrm{~A}$ civil initiative that tracks government intervention in the internet estimates the number of blocked websites to be above 103,625, half of which were blocked in $2015 .{ }^{103}$ This initiative also reports that it is the TIB that underwrote $94 \%$ of such decisions.

Defamation lawsuits have complemented the AKP's attempts to suppress freedom of expression. These lawsuits have targeted journalists as well as hundreds of people from all walks of life, including artists, actors, sculptors, composers and ordinary citizens, including underage students. ${ }^{104}$ Their statements and social media posts became the target of government surveillance. Figure 2 shows the increase in the number of individuals facing 


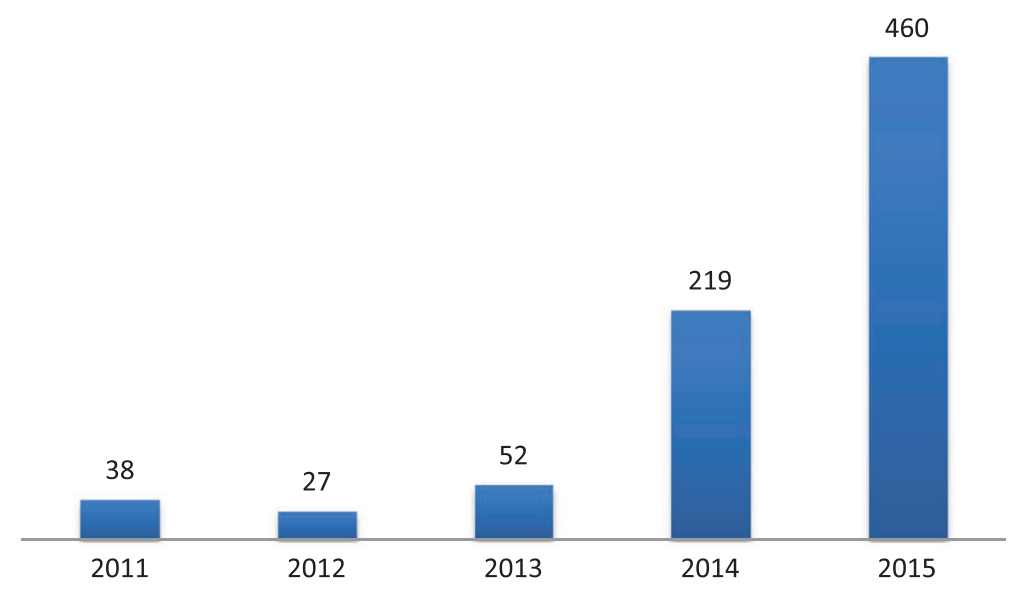

Figure 2. Number of individuals facing defamation lawsuits filed by Erdogan. Source: Original data compiled by the authors from media reports on defamation lawsuits filed by Erdogan between January 2011 and October 2015.

defamation lawsuits since 2011. In 2015, of 460 people investigated for insulting Erdogan, 50 were journalists, while 281 were members of formal opposition. In the 307 lawsuits Erdogan has filed since 2011, he received 1,031,243 Turkish lira as indemnity.

Severe restrictions over freedom of expression are manifest in the European Court of Human Rights' decisions on Turkey. Accordingly, the nature of civil liberties violations under the AKP government registered by the Court has changed over the years. Between 2011 and 2013 the Turkish state was indicted for frequent violations of the right to a fair trial, property rights, and the right to liberty and security (which concerns issues pertaining to arrest and detention). In 2014, however, violations of freedom of expression ranked third in the list after the right to liberty and security and the right to a fair trial. ${ }^{105}$

\section{Repression of opposition and freedom of assembly}

In its 2014 report Human Rights Watch asserts:'In office for twelve years under the leadership of Recep Tayyip Erdoğan the AKP has shown increasing intolerance of political opposition, public protest, and critical media'. ${ }^{106}$ The police have used extensive and disproportionate force against the people in anti-government demonstrations and public protests organised by students, unions, professional associations and environmentalists. ${ }^{107}$ Police brutality reached a new peak during the Gezi protests in 2013, when riot police punished protesters with extensive and unlawful use of teargas as a lethal weapon. In the nation-wide protests five protesters were killed and more than 9000 were injured, some with severe injuries in their eyes or heads. Following the Gezi protests, the ruling party sustained its intolerance of dissent and brutally suppressed peaceful activists demonstrating after a mining accident in 2014, the May Day celebrations in Taksim square in 2014 and 2015, the Gezi anniversaries, the LGBT pride parade in 2015 and, most recently, after suicide bombings in Ankara in October 2015.

In this spirit activists and students who participated in anti-government protests were detained for several months for alleged violations of the anti-terror law. This systematic harassment took a new turn after the Gezi protests. Since then 5500 protesters have faced charges of terrorism, participating in unauthorised demonstrations, resisting the police, 
and damaging public property. ${ }^{108}$ The government also targeted organised civil society to silence the power of critical voices. Among those who were brought before the courts after the Gezi protests were also representatives of professional associations, most notably the Medical Association, Engineers' Association and Architects' Association. Representatives of Taksim Solidarity, composed of dozens of civil society organisations with the aim of preserving Gezi Park, were detained and accused in court of 'founding a criminal organisation' with the intention of inciting violence. ${ }^{109}$ The government also launched investigations into football fan groups and their role in the protests. Thirty-five members of a football fan group in Turkey, cArsi, were tried for attempting a coup d'etat facing life sentences, yet recently have been acquitted. ${ }^{110}$

In addition to directly punishing dissent, the AKP government also looked into the finances of independent voices in society. Along these lines in late 2013 the party passed a bill stripping the Union of Chambers of Turkish Architects and Engineers of its financial resources and removing it from all city-planning decisions. ${ }^{111}$ Similarly the government also targeted businessmen who criticised the party's handling of the protests and allegedly provided logistical and financial support to the protesters. For instance, companies affiliated with Koc Holding and Boydak Holding faced extraordinary tax inspections immediately after the Gezi protests. ${ }^{112}$

Moreover, the government securitised dissent through public-policy instruments. The most significant of these steps is the National Security Council document adopted in April 2015. Now controlled by the AKP government, the MGK specified internal opposition activities as the most important threat to security in Turkey and adopted an action plan to deal with civil disobedience, social media activism encouraging dissent, and all'acts undermining the nation's will.' ${ }^{13}$ To complement this MGK document with further legal measures, the AKP-controlled parliament passed 'the Internal Security Package' in March 2015 to expand the authority of the riot police during protests, including the right to open lethal fire at protesters, extend legal detention periods and limit the scope of court approval for police searches, detainments and wiretapping. ${ }^{114}$

Finally, to ensure their complicity in these successive waves of violence, the government took steps to protect police forces from judicial scrutiny, thereby deepening the culture of impunity in Turkey. ${ }^{115}$ The AKP government proved to be extremely reluctant to launch investigations into disproportionate police violence employed against the protesters during and after the Gezi protests. While the judicial system was slow to hold those who were responsible accountable, Erdogan supported police brutality with public statements praising the police's way of handling the protests. The AKP's violations of civil liberties are reflected in Freedom House's civil liberties scores for Turkey, as shown in Figure 3.

\section{Conclusion: Quo Vadis Turkey?}

Thanks to the presence of electoral competition, CA regimes are inherently unstable and can witness electoral upsets. ${ }^{116}$ Unless the incumbent reverts to highly repressive measures to drive the opposition underground, opposition forces can mobilise public opinion to challenge the government electorally. Indeed, the AKP's failure to secure a parliamentary majority in the June 2015 elections, ${ }^{117}$ despite its considerable resource advantages and media support, fits this pattern. In line with our classification of the Turkish case as competitive authoritarian, the ruling party did not engage in massive vote rigging or disenfranchisement 


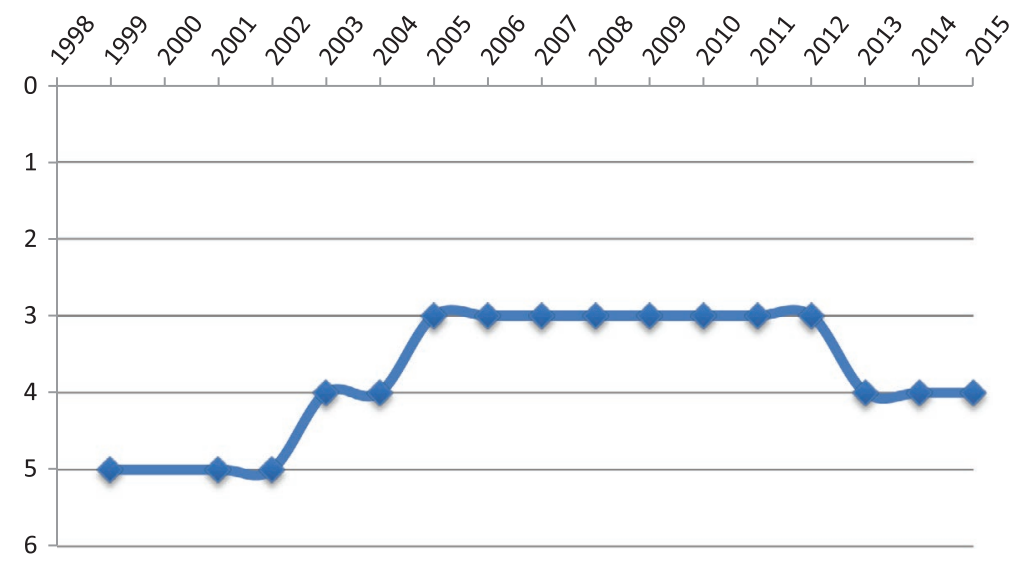

Figure 3. Turkey's civil liberties scores. Source: Compiled from Freedom House, "Freedom in the World" reports: Turkey, 1998-2015, http://www.freedomhouse.org/.

and instead exploited the uneven playing field to keep intact its cross-class coalition - a strategy that was sufficient for a parliamentary plurality yet insufficient for a majority when the HDP crossed the $10 \%$ electoral threshold.

Because of their political hegemony, however, the incumbents in CA regimes may retain their control over the state apparatus even after an electoral defeat. This was epitomised in the Turkish context by Erdogan, who, in contravention of the Constitution that mandates a non-partisan president, ${ }^{118}$ has sought to shape the political arena after the June election. The party also continued to exercise power thanks to deep divisions within the opposition. After the June 2015 election the MHP leader Devlet Bahceli's statement that his party would not support nor participate in a coalition government endorsed by the HDP eliminated the only coalition option that could have pushed the AKP out of power. This set the stage for Erdogan to reportedly block the AKP and CHP from reaching a compromise that would have paved the way for a grand coalition. After the breakdown of these talks, Erdogan refused to give the main opposition leader, Kilicdaroglu, the mandate to form a new government and instead let the constitutionally sanctioned 45-day mark expire to call for a snap election. Given his insistence on letting only Davutoglu lead the negotiations, moreover, Erdogan kept the AKP in power through an interim government, despite the absence of sufficient popular support and political legitimacy. The fact that the bureaucracy remained strongly tied to the AKP in this period allowed the party elites to continue governing the country. ${ }^{119}$

If the results of the June election reinforced the competitive aspects of the Turkish regime, the AKP campaign for the November election emphasised its authoritarian elements. International observers of the election are at a consensus that the campaign period was surrounded by'a climate of violence and fear,', ${ }^{\prime 20}$ as gross violations of civil liberties and attacks on press freedom hindered the ability of the opposition to compete against the ruling party. ${ }^{121}$ More than any other election in the post-1980 period, the November campaign was marred by violence, ${ }^{122}$ polarisation ${ }^{123}$ and inter-ethnic conflict, ${ }^{124}$ as already discussed. Police raids against opposition parties, media organizations ${ }^{125}$, and polling agencies that showed the AKP's vote in decline since the June election, ${ }^{126}$ characterised the period between two elections.

Against the background of ethnic violence, economic uncertainty and political polarisation, the AKP promoted the propaganda that Erdogan's Turkey was attacked by a coalition of 
outside powers and called for national unity under a single-party government. They used the pro-government media to threaten voters that the AKP's defeat in November would either result in yet another snap election, ${ }^{127}$ or lead to higher unemployment rates, ${ }^{128}$ and a return to authoritarian practices reminiscent of the 1990s in the Kurdish populated provinces. ${ }^{129}$

In what came as a surprise to most analysts and pollsters alike, the ruling AKP registered a major victory in the November election, increasing its vote share from $41 \% 49 \%$ and gaining nearly five million extra votes in just five months. Moreover, its vote share increased in every province, a clear sign of the party's continued ability to draw votes from a plethora of constituencies, including both conservative Turkish and Kurdish voters. After a brief interruption following the June election, the results of the November election thus consolidated the competitive authoritarian regime in Turkey under the AKP's dominant-party rule. The fact that the AKP managed to hold onto power by stretching its constitutional mandate, despite losing its parliamentary majority in June, is a key factor in understanding not only the party's electoral success, but also the intricate nature of the party's authoritarian tendencies. The AKP victory can only be seen in the context of rising competitive authoritarianism in Turkey. The AKP successfully presented itself as the only viable option in the midst of economic and political crises by building on its past record and at the same time skewing the playing field against the already weak and divided opposition.

The future of the political system in Turkey is still uncertain, since the AKP fell short of the minimum number of seats required to amend the constitution through a national referendum, which would instate a presidential system, thus institutionalising Erdogan's monopoly over power and potentially instigating a drift towards hegemonic authoritarianism. For now, as has been evident since June 2015, Turkey is a competitive authoritarian regime par excellence. It is not solely the uneven playing field or systematic violations of civil liberties but also innate political instability - inherent features of competitive authoritarianism - that now characterise the Turkish regime. Whether or not Turkey can take an exit from this predicament is as yet unknown. Further research on the economic pillars on which this competitive authoritarian regime rests is needed to provide us with plausible answers on how the AKP may consolidate its power and whether the opposition can undermine its rule in the years to come.

In memory of Tahir Elçi, Kurdish lawyer and human rights activist, who was killed in Diyarbakır in December 2015.

\section{Disclosure statement}

No potential conflict of interest was reported by the authors.

\section{Acknowledgements}

Special thanks are due to Hazan Sucu for her valuable research assistance. We would also like to thank Karabekir Akkoyunlu, Tim Dorlach, Samuel Greene, Kerem Oktem, Ziya Onis, Osman Savaskan, Feryaz Ocakli, Andreas Schedler and participants at the interdisciplinary workshop on the'Political Economy of Contemporary Turkey' (July 30-31, 2015), the inaugural symposium 'Consortium of European Symposia on Turkey' (October 1-3, 2015) and the 'Rise of Competitive Electoral Authoritarian Regimes' panel at APSA 2015. We are grateful to two anonymous reviewers for their insightful comments and suggestions. 


\section{Notes on Contributors}

Berk Esen is an Assistant Professor of International Relations at Bilkent University. Before joining Bilkent, he worked as a Post-doctoral Research Fellow at Sabancı University and received his PhD in Government from Cornell University. His research interests include the political economy of development, democratisation, and political parties, with a regional focus on Latin America and the Middle East. His most recent article, entitled "Nation-building, Partystrength, and Regime Consolidation: Kemalism in Comparative Perspective", was published in the special December 2014 issue of Turkish Studies.

Sebnem Gumuscu is an Assistant Professor of Political Science at Middlebury College. Her work focuses on political Islam, dominant parties, democratisation and democratic erosion, and the politics of the Middle East and North Africa. Her research has appeared in Comparative Political Studies, Government and Opposition, and Middle Eastern Studies. Her recent book, co-authored with E. Fuat Keyman, Democracy, Identity, and Foreign Policy in Turkey: Hegemony through Transformation (2014), examines Turkey's transformation under the Justice and Development Party since 2002.

\section{Notes}

1. "Erdogan: 400 vekil alinsaydi durum farkli olurdu." Cumhuriyet, September 8, 2015. http://www. cumhuriyet.com.tr/video/video/363925/Erdogan_400_vekil_alinsaydi_farkli_olurdu.html\#.

2. For Hurriyet's official response to this charge, see "Hurriyet ve Erdogan'in 400 vekil sozu." Hurriyet, September 8, 2015. http://sosyal.hurriyet.com.tr/yazar/faruk-bildirici_484/hurriyet-ve-erdoganin-400-vekil-sozu_30020005.

3. "PKK Attacks kill Soldiers in Southeastern Turkey." BBC, September 7, 2015. http://www.bbc. com/news/world-europe-34169988; "AK Parti milletvekili saldirganlara boyle hitap etti: 1 Kasim'dan sonra defolup gidecekler." Hurriyet, September 7, 2015. http://www.hurriyet.com.tr/ gundem/30007675.asp; and "Boynukalin Hurriyete saldiriyi boyle savundu: Bir dokunulmazligi kaldirdik." Radikal, October 21, 2015. http://www.radikal.com.tr/turkiye/boynukalin-hurriyetesaldiriyi-boyle-savundu-bir-dokunulmazligi-kaldirdik-1456745/.

4. "Polis polisin gorev yapmasini engellerse." Hurriyet, September 12, 2015. http://sosyal.hurriyet. com.tr/yazar/mehmet-y-yilmaz_148/polis-polisin-gorev-yapmasini-engellerse_30052858.

5. Scholars have noted the proliferation of hybrid regimes - cases that are neither fully democratic nor authoritarian - in the post-cold war period. See Levitsky and Way. "The Rise of Competitive Authoritarianism"; Levitsky and Way, Competitive Authoritarianism; Schedler, Electoral Authoritarianism; Carothers, "The End of the Transition Paradigm"; and Diamond, "Thinking about Hybrid Regimes." For a recent analysis, see Diamond, "Facing up to the Democratic Recession."

6. Muftuler-Bac and Keyman, "The Era of Dominant-party Politics"; Turam, "Are Rights and Liberties Safe?"; Önis, "Sharing Power," 100-122; Önis, "Monopolising the Centre"; Özbudun, "AKP at the Cross-roads"; Lancaster, "The Iron Law of Erdogan"; and Tas, "Turkey."

7. See Diamond, "Facing up to the Democratic Recession"; and Özbudun, "Turkey's Judiciary."

8. We adapt Dahl's seven criteria - elected officials, free and fair elections, inclusive suffrage, the right to run for office, freedom of expression, alternative information, and associational autonomy - as the minimum requirements of democracy. Dahl, Polyarchy. Except for having elected officials, inclusive suffrage and the right to run for office, Turkey no longer satisfies these minimum criteria of democracy. Elections are no longer fair, while freedom of information, expression and association have been systematically curtailed by the AKP government, as discussed in detail in the rest of the paper.

9. Levitsky and Way, Competitive Authoritarianism, Appendix. 
10. Levitsky and Way. "The Rise of Competitive Authoritarianism," 51-65; and Levitsky and Way, Competitive Authoritarianism.

11. Levitsky and Way, Competitive Authoritarianism, 5.

12. Özbudun, "AKP at the Cross-roads"; Söyler, "Informal Institutions"; and Tas, "Turkey."

13. Taskin, "Hegemonizing Conservative Democracy"; Özbudun, "AKP at the Cross-roads"; Özbudun, "Turkey's Judiciary"; Önis, "Monopolising the Centre"; and Çinar and Sayin, "Reproducing the Paradigm of Democracy."

14. Diamond, "Thinking about Hybrid Regimes," 170. See also Schedler, Electoral Authoritarianism. The concept of electoral authoritarianism better captures regime change in Turkey, yet it hides the difference between this new regime and hegemonic authoritarianism. All electoral authoritarian regimes conduct regular elections. In competitive authoritarian regimes - a subset of electoral authoritarianism - however, the outcome of elections is uncertain, as the June 2015 elections in Turkey show. In hegemonic authoritarian regimes, in contrast, elections are manipulated and rigged to prevent any surprises at the ballot box. For a discussion of their differences, see Diamond, "Thinking about Hybrid Regimes," 173-175.

15. Levitsky and Way, Competitive Authoritarianism.

16. Tas, "Turkey." Özbudun was the first scholar to apply this term to the Turkish context. However, similarly to Tas, we disagree with Özbudun's depiction of 1990s Turkey as a 'delegative democracy'. Unlike delegative democracies, where incumbents hold excessive powers and carry weak horizontal accountability, the civilian leadership in Turkey at that time was not dominant over the military and thus failed to limit its reserve domains.

17. For the effect of polarisation in Turkish politics, see Yardimci-Geyikci, "Gezi Park Protests."

18. O'Donnell, "Delegative Democracy."

19. Lancaster, "The Iron Law of Erdogan."

20. Moreover, institutionalisation of this de facto situation and transfer of executive power to the elected president requires a new constitution. That is why Erdogan does not refrain from violating the norms of impartiality and campaigning in favour of the AKP, with the aim of attaining a qualified majority in parliament.

21. Similarly to the Turkish case, both Hungary and Thailand recently witnessed the rise of conservative populist leaders who, once in power, began to remove democratic restraints on the executive, manipulated the electoral system, and curtailed the democratic space available to opposition. As a result of a standoff between large segments of the urban middle classes and the Thai Prime Minister, Thaksin Shinawatra, over questions of executive outreach and corruption, the military has twice staged a coup over the past decade - in 2006 and 2011. This conflict between Thaksin's movement and the military at times resembled the AKP's struggle against the Turkish military during its first term. For a comparison of the two cases, see Zarakol, Revisiting Second Image Reversed; and McCargo and Zarakol, Turkey and Thailand. Winning a landslide victory in the 2010 Hungarian general elections with 53\% of the vote, Victor Orban's Fidezs party used its parliamentary super-majority to revise the electoral system, adopt a new constitution and change the composition of the Constitutional Court.

22. Söyler, "Informal Institutions."

23. We define tutelary democracy as a type of diminished democracy, in which the elected government's power is restrained by the military (or another veto player such as the Constitutional Court), which intervenes in the political process through informal and usually extra-constitutional channels. For more on this concept, see Wigell, "Mapping 'Hybrid Regimes"'

24. The National Security Council was established after the first military intervention in 1960 to institutionalise the military's oversight over civilian politicians. The power and responsibilities of the council were expanded with the 1980 intervention, which allotted substantial power and influence to the military in a wide range of political decisions from security to education.

25. Kuru, "The Rise and Fall of Military Tutelage in Turkey," 44; Söyler, "Informal Institutions," 325; and Gürsoy, "The Changing Role of the Military," 749.

26. Aydinli, "Turkey under the AKP," 103.

27. Kuru, "The Rise and Fall of Military Tutelage in Turkey," 50; Sarigil, "Civil-Military Relations;" and Satana, "Transformation of the Turkish Military." 
28. Of course, these reforms succeeded in effectively reducing the role of the military in Turkish politics, partly thanks to support given by a group in the military who sided with democracy. Aydinli, "Turkey under the AKP." Unfortunately, however, scholars who accepted the validity of these exposed coup plots with few reservations were oblivious to the gross injustices committed during the lengthy trials that followed. Much of the evidence initially presented against the officers proved to be fabricated. Instead of leading to democratic consolidation, these trials polarized society, eroded the rule of law, and were eventually dropped by the AKP government, which no longer saw the trials as serving its partisan interests. See Gürsoy, "The Changing Role of the Military."

29. Carkoglu and Toprak, Religion, Society and Politics.

30. See Akturk, Regimes of Ethnicity and Nationhood.

31. On the party's rise to predominance, see Gumuscu, "The Emerging Predominant Party System"; Ayan Musil, "Emergence of a Dominant Party System"; Taskın, "Hegemonizing Conservative Democracy"; and Cınar, "Local Determinants."

32. Gumuscu and Sert, "The March 2009 Elections."

33. An Islamic preacher by profession, Fethullah Gulen is the leader of a pseudo-religious movement that oversees a large network of schools in more than 80 countries, including the USA, where the movement is the largest operator of charter schools in the country. In the past decade Gulen's followers have reached positions of influence in the state bureaucracy, judiciary and academia and are well-organised among businessmen and journalists. Once close allies during the struggle against the Kemalist establishment, the Gulenist movement and Erdogan's AKP began to clash after 2011, reportedly over the question of power sharing. This rift triggered a contentious fight between the two groups after late 2013, with Erdogan using his political capital to weed out Gulen sympathisers in the bureaucracy and to co-opt or destroy the main Gulenist actors in the media, business and education. For more information on Fethullah Gulen and his movement, see Turam, Between Islam and the State; and "Who is Fethullah Gulen?"City Journal, Autumn 2012. http://www.city-journal.org/2012/22_4_fethullah-gulen.html.

34. Dogan and Rodrik, Yargı, Cemaat ve Bir Darbe Kurgusunun Icyuzu; and Dogan and Rodrik, "A Harvard Economist."

35. For details on the 2010 referendum, see Özbudun, "AKP at the Cross-roads"; Özbudun, "Turkey's Judiciary"; and Kalaycioglu, "Kulturkampf in Turkey."

36. On the importance of a level playing field for democratic outcomes, see Levitsky and Way, "Why Democracy needs a Level Playing Field."

37. Clearly, Turkey is not a full authoritarian regime since nation-wide elections continue and there is no large-scale falsification of results; no major opposition party is routinely excluded from competition; and repression is not yet sufficiently widespread to force opposition groups underground. For details, see Levitsky and Way, Competitive Authoritarianism, Appendix.

38. Ibid.

39. Tol and Hjerno, "Turkey's General Elections"; and Ciddi, "Turkey's September 12, 2010, Referendum." http://www.rubincenter.org/2011/12/turkey\%E2\%80\%99s-september-12-2010referendum/.

40. Independent researchers who conducted analyses of the preliminary results in the Ankara municipality race detected a positive relationship between the AKP-CHP vote margin and invalid vote share, even after controlling for fixed effects related to district- (ilce) and votingstation- (alan) level factors. Erik Meyersson, "Trouble in Turkey's Elections." April 6, 2014. http:// erikmeyersson.com/2014/04/06/trouble-in-turkeys-elections; Cem Say, "Istatistik bilimi, secimlerde CHP'ye karsi guclu hile ihtimalini gosteriyor." Cumhuriyet, April 7, 2014. http://www. cmpe.boun.edu.tr/ say/cum7nis.htm; and Arbatli, Cemal, "What happened in 2009 Ankara Elections?" April 30, 2014. http://ekonomisiyaset.blogspot.ru/2014/04/what-happened-inankara-2009-elections.html.

41. "Ankara'da 24 saatlik skandal." Cumhuriyet, April 1, 2014. http://www.cumhuriyet.com.tr/haber/ siyaset/56167/Ankara_da_24_saatlik_skandal.html; and "Antalya'da tartisilan fotograf." April 2, 2014. http://www.hurriyet.com.tr/antalyada-tartisilan-fotograf-26132116. 
42. For instance, formal complaints by the main opposition Republican People's Party (CHP) to get an official recount were rejected by local, provincial and supreme electoral boards.

43. Ezgi Basaran, "Secim sonuclarina guvenilmeyeceginin somut kanitini buldum." Radikal, June 3, 2014. http://www.radikal.com.tr/yazarlar/ezgi_basaran/secim_sonuclarina_guvenilemeye ceginin_somut_kanitini_buldum-1195251.

44. "Oy ve Otesinin altindan da Feto cikti." Sabah, October 21, 2015. http://www.sabah.com.tr/ gundem/2015/10/21/oy-ve-otesinin-altindan-da-feto-cikti.

45. "Secim sonuc degerlendirmeleri." Oy ve Otesi, November 3, 2015. . http://oyveotesi.org/1-kasim2015-genel-secimleri/1-kasim-2015-secim-sonuc-degerlendirmeleri/.

46. "HDP'nin Mitingi Basbakanin programina takildi." Milliyet, April 24, 2014. http://www.milliyet. com.tr/hdp-nin-mitingi-basbakan-in/siyaset/detay/2049275/default.htm.

47. "Insan Haklari Dernegi Genel Merkez Aciklamasi." June 6, 2015. http://www.ihd.org.tr/hdpyeyonelik-bombali-ve-silahli-saldirilari-kiniyor-sorumlulari-lanetliyoruz/.

48. For a fairly comprehensive list of attacks on the HDP and the number of party members detained or arrested, see "HDP'ye yapilan saldirilar ve cezasizlik sistemli mi?"T24, May 18, 2015. http:// t24.com.tr/haber/hdpye-yapilan-saldirilar-ve-cezasizlik-sistemli-mi,296981. We thank an anonymous reviewer for bringing this source to our attention.

49. "Istanbulda 15 HDP uyesi tutuklandi." Radikal, October 6, 2015. http://www.radikal.com.tr/ turkiye/istanbulda_15_hdp_uyesi_tutuklandi-1446014; and "Ankarada HDP'ye operasyon." IMCTV, October 6, 2015. http://www.imctv.com.tr/ankarada-hdpye-operasyon-23-gozalti/.

50. The chief prosecutor in Ankara reported that the attacks on the peace rally were carried out by an ISIS cell in Turkey. "Ankara Bassavciligi: Ankara saldirilarini ISID duzenledi." BBC, October 28, 2015. http://www.bbc.com/turkce/haberler/2015/10/151028_ankara_saldiri_savcilik.

51. "HDP secim mitinglerini iptal etti." IMCTV, October 16, 2015.

52. "YSK'dan Erdogan itirazlarina red." Hurriyet, May 6, 2015, http://www.hurriyet.com.tr/ gundem/28928070.asp; and "YSK'da iki cesur yurek." Cumhuriyet, May 15, 2015. http://www. cumhuriyet.com.tr/haber/turkiye/276875/YSK_de_iki_cesur_yurek.html.

53. "AKP'de esbaskanlik donemi." Diken, May 18, 2015. http://www.diken.com.tr/akpde-esbaskanlik-sistemi-davutoglu-ve-erdoganin-mitingleri-birbirlerini-tamamliyor/.

54. "Vali ve Komutan AKP adayiyla secim turunda." Taraf, May 20, 2015. http://www.taraf.com.tr/ politika/yok-artik-bu-kadar-da-olmaz-vali-ve-komutan-akp-adayiyla-secim-turunda/.

55. "Davutoglu'ndan skandal mektup." Zaman, June 2, 2015. http://www.zaman.com.tr/politika_ davutoglundan-skandal-mektup_2297870.html.

56. "Hollanda: Davutoğlu imzalı mektuba soruşturma." BBC Turkce, October 20, 2015. http://www. bbc.com/turkce/haberler/2015/10/151020_hollanda_sorusturma_davutoglu.

57. "MHP says Istanbul Municipal Police tore Campaign Banners." Today's Zaman, May 11, 2015. http://www.todayszaman.com/national_mhp-says-istanbul-municipal-police-tore-campaignbanners-takes-legal-action_380429.html.

58. "Main Opposition CHP's Truck Towed Away." Hurriyet Daily News, May 29, 2015. http://www. hurriyetdailynews.com/main-opposition-chps-election-truck-towed-away-in-erzurum. aspx?PagelD=238\&NID=83172\&NewsCatID=338.

59. "Mahkeme, MHP'nin hirsiz afislerini suclu buldu." October 25, 2015. http://www.rotahaber. com/siyaset/mahkeme-mhp-nin-hirsiz-afislerini-suclu-buldu-h532785.html; and "MHP'nin Osmanlica hirsiz pankarti kaldirildi." Cumhuriyet, December 29, 2014. http://www.cumhuriyet. com.tr/haber/turkiye/175773/MHP_nin_Osmanlica_Hirsiz_pankarti_kaldirildi.html\#.

60. "AK Partili belediye MHP secim burosunu muhurledi." Cihan, May 10, 2015. http://www.cihan. com.tr/tr/ak-partili-belediye-mhp-secim-burosunu-muhurledi-1783044.htm.

61. Reporters without Borders also highlighted biased broadcasting by the TRT and confirmed the existence of political pressure on the critical media outlets. See http://en.rsf.org/turkeyban-sought-turkish-authorities-try-22-05-2015,47922.html. For more details on the AKP's colonisation of TRT, see Dagistanli, 5N1 Kim.

62. "OSCE Secim Gozlem Misyonu Raporu." October 22, 2015. http://www.osce.org/tr/ odihr/86845?download=true. 
63. "TRT'de konuk dağılımı: AKP 37, CHP, HDP ve MHP 0." Radikal, October 30, 2015. http://www. radikal.com.tr/politika/trtde-konuk-dagilimi-akp-37-chp-hdp-ve-mhp-0-1462892/.

64. "OSCE Secim Gozlem Misyonu Raporu." October 22, 2015. http://www.osce.org/tr/ odihr/86845?download=true.

65. "Ahmet Hakan'a saldirmakla suclanan 7 zanlı adliyeye sevkedildi." BBC Turkce, October 4, 2015. http://www.bbc.com/turkce/haberler/2015/10/151004_ahmethakan_adliye.

66. "AKPM'nin 7 Haziran Raporu aciklandi,"T24, June 22, 2015. http://t24.com.tr/haber/akpmnin7-haziran-raporu-aciklandi,300483.

67. "Turkey's state run TV refuses to air CHP Ad targeting Government." Hurriyet Daily News, April 11, 2015. http://www.hurriyetdailynews.com/turkeys-state-run-tv-refuses-to-air-chp-ad-targetinggovt.aspx?pagelD=517\&nID=80920\&NewsCat $\mid \mathrm{D}=338$.

68. "Fetih Soleni icin ogrenci ve ogretmenlere zorunlu gorev." Radikal, May 28, 2015. http://www. radikal.com.tr/turkiye/fetih_soleni_icin_ogrenci_ve_ogretmenlere_zorunlu_gorev-1367989.

69. "Seçimde iki kat örttüler." Cumhuriyet, June 15, 2015. http://www.cumhuriyet.com.tr/haber/ ekonomi/299587/Secimde_iki_kat_orttuler.html.

70. "Ortulu odenek bilancolari." Cumhuriyet, December 20, 2014. http://www.cumhuriyet.com.tr/ koseyazisi/167583/Ortulu_Odenek_Bilancolari.html.

71. "CHP warns YSK about PM's Possible Use of Discretionary Fund for Race." Today's Zaman. July 3, 2014. http://www.todayszaman.com/national_chp-warns-ysk-about-pms-possible-use-ofdiscretionary-fund-for-race_352026.html.

72. Whereas Erdogan's campaign fund received over 55 million lira's-worth of donations, his closest rival, Ekmeleddin Ihsanoglu, could muster only 8.5 million lira. "Erdogan bagis miktarini acikladi." Hurriyet, August 9, 2014. http://www.hurriyet.com.tr/gundem/26971638.asp.

73. "Iste gercek faiz lobisi Zorlu'dan AKP'ye 40 bin Ramazan kolisi." Sol, July 27, 2013. http://haber. sol.org.tr/devlet-ve-siyaset/iste-gercek-faiz-lobisi-zorludan-akpye-40-bin-ramazan-kolisihaberi-77078.

74. "AKP'nin yeraltı prensi Gurkan." Taraf, May 16, 2014. http://arsiv.taraf.com.tr/yazilar/huseyinozay/akpnin-yeralti-prensi-gurkan/29765.

75. "Ihale icin iscileri mitinge goturduk." BBC, August 19, 2015. http://www.bbc.com/turkce/ haberler/2015/08/150819_soma_dava.

76. For details of the case, see "Deniz Feneri e. V. davasına Turkiye'de ceza yok." Hurriyet, May 14, 2015. http://www.hurriyet.com.tr/ekonomi/28998561.asp.

77. In December 2013 Turkish police arrested the sons of three then cabinet ministers, the general manager of a state bank, an AKP mayor and several businessmen accused of influence-peddling, tender-fixing, bribery, embezzlement and gold smuggling to Iran.

78. For a list of businessmen and their donations to TURGEV, see "9 soruda Turgev." November 16, www.diken.com.tr/9-soruda-turgev.

79. "99 milyon 999 bin 990 dolar bağışmış." Cumhuriyet, April 9, 2014. http://www.cumhuriyet.com. tr/haber/turkiye/59069/99_milyon_999_bin_990_dolar_bagismis.html\#.

80. "SDP baskani Ayhan Ogan Ogun Habere konustu," January 9, 2014. http://www.ogunhaber. com/haber/sdp-baskani-ayhan-ogan-ogunhabere-konustu-haberi-237313h.html.

81. Corke et al., Democracy in Crisis.

82. For a detailed assessment of the structure of the media sector and freedom of the press in Turkey, see Kurban and Sözeri, "Caught in the Wheels of Power."

83. As the Freedom House report asserts, "newspapers critical of the government have been subjected to tax inspections on a regular basis, with papers such as Taraf receiving huge tax fines, while pro-government newspapers such as Sabah are not subjected to similar scrutiny. Taraf newspaper reported that it faced three tax inspections over the past eight months and had incurred fines which it argued were selectively applied and not faced by the pro-government media." Corke et al., Democracy in Crisis.

84. European Commission, "Turkey 2009 Progress Report"; and European Commission, "Turkey 2010 Progress Report."

85. Soon after the sale of these newspapers, Dogan Media negotiated a settlement with the government and restructured its tax fine. 
86. Corke et al., Democracy in Crisis.

87. "Cemaate yakin kanallar Turksat platformlarindan cikarildi." Al Jazeera Turk, October 12, 2015. http://www.aljazeera.com.tr/haber/cemaate-yakin-kanallar-turksat-platformlarindan-cikarildi; and "Kanaltürk bütün programlarını bitirdi." Radikal, November 17, 2015. http://www.radikal. com.tr/hayat/kanalturk-butun-programlarini-bitirdi-1474152/.

88. "Mustafa Varank'tan Cumhuriyet'e tepki: Gurur duydum." Star, October 24, 2015. http://haber. star.com.tr/medya/mustafa-varanktan-cumhuriyete-tepki-gurur-duydum/haber-1064988.

89. For more details, see Dagistanli, 5 N1 Kim. A number of these calls, personally made by Erdogan, were leaked in the early months of 2014, indicating the unprecedented level of control and pressure over the mainstream media.

90. "TRT'nin 25 günlük siyasi bilançosu: AKP tek başına iktidar." Radikal, October 27, 2015. http://www. radikal.com.tr/politika/trtnin-25-gunluk-siyasi-bilancosu-akp-tek-basina-iktidar-1460331/.

91. For cases, see Corke et al., Democracy in Crisis, 8-9.

92. "Medya Gozlem Raporu 2014." October 15, 2015 and "Medyanin 3 yili," March 4, 2015. Both on Bianet, http://www.bianet.org/bianet/medya/162748-medyanin-3-yili-grafik-ozet.

93. Lowen, "The Problem with insulting Turkey's President Erdogan." BBC, April 16, 2015. http:// www.bbc.com/news/world-europe-32302697.

94. Freedom House, Freedom in the World Country Reports: Turkey. The government publicly defended the detention of journalists in cases like KCK and Ergenekon, equating journalistic activities with acts of terrorism.

95. Arsan, "Sivil Itaatsizlik Baglaminda Bir Arastirma."

96. Corke et al., Democracy in Crisis. See also Dagistanli, 5N1Kim.

97. European Commission, "Turkey 2010 Progress Report."

98. "12 soruda Deniz Feneri davası." Radikal, September 11, 2008. http://www.radikal.com.tr/ turkiye/12-soruda-deniz-feneri-davasi-898145/.

99. We thank Selver Sahin for this link. "10 Issues Turkish Media is banned from Reporting On." Hurriyet Daily News, November 27, 2014. http://www.hurriyetdailynews.com/10-issues-turkishmedia-is-banned-from-reporting-on.aspx?pagelD=238\&nID=74904\&NewsCatID=339.

100. For further details, see "World Press Freedom Index," http://index.rsf.org/\#!/index-details/TUR.

101. For an assessment of the AKP government's internet regulations, see Kinikoglu, “Evaluating the Regulation of Access."

102. Corke et al., Democracy in Crisis.

103. For more details, see http://engelliweb.com/istatistikler/; and “Özgürlük için Basın Ekim 2015 raporu açıklandı."November 20, 2015. http://tr.pressforfreedom.org/ozgurluk-icin-basin-ekim2015-raporu-aciklandi/.

104. "12 ve 13 yaşındaki 2 çocuğa dava." Hurriyet, October 27, 2015. http://www.hurriyet.com.tr/12ve-13-yasindaki-2-cocuga-dava-40006868?utm_source=sm_tw\&utm_medium=free\&utm _ term=post\&utm_content=\&utm_campaign=12-ve-13-yasindaki-2-cocuga-dava-40006868_.

105. "Statistics," Insan Haklari Daire Baskanligi. http://www.inhak.adalet.gov.tr/istatistik/istatistikler. html. For an interview conducted with a Turkish judge at the European Court of Human Rights on Turkey's growing human rights violations under AKP rule, see "AiHM Başkan Yardımcısı Işıl Karakaş: Cumhurbaşkanına hakaret davası Avrupa'da yok." Hurriyet, September 27, 2015. http://www.hurriyet.com.tr/aihm-baskan-yardimcisi-isil-karakas-cumhurbaskanina-hakaretdavasi-avrupa-da-yok-30174841.

106. HRW, Turkey's Human Rights Rollback.

107. "CHD tutuklu ogrenci raporunu acikladi." Cumhuriyet, October 5, 2011. http://www.cumhuriyet. com.tr/haber/diger/287758/CHD_tutuklu_ogrenci_raporunu_acikladi.html; and European Commission, "Turkey 2011 Progress Report."

108. HRW, Turkey's Human Rights Rollback.

109. Ibid.

110. Ibid.

111. "TMMOB'un vize yetkisi Cevre Bakanligi'na verildi."CNNTurk, July 10, 2013. http://www.cnnturk. com/2013/ekonomi/genel/07/10/tmmobun.vize.yetkisi.cevre.bakanligina.verildi/714804.0/; and "Turkey's Rebellious Chamber to attend Meetings abroad only with Permission from 
Ministry." Hurriyet Daily News, December 25, 2014. http://www.hurriyetdailynews.com/Default. aspx?pageID=238\&nID=76092\&NewsCatID=341.

112. "Maliye'den Koc sirketleri Tupras ve Aygaz'a ani denetim." Radikal, July 24, 2013. http://www. radikal.com.tr/ekonomi/maliyeden-koc-sirketleri-tupras-ve-aygaza-ani-denetim-1143226/; and "Koca destek veren Boydak'in sirketlerine vergi denetimi." Radikal, November 29, 2013. http://www.radikal.com.tr/ekonomi/koca-destek-veren-boydakin-sirketlerine-de-vergidenetimi-1163560/.

113. "Sivil itaatsizlik ve kaosa tesvik kirmizi kitapta." Haberturk, April 7, 2015. http://www.haberturk. com/gundem/haber/1062804-sivil-itaatsizlik-ve-kaosa-tesvik-kirmizi-kitapta.

114. "Ic Guvenlik Yasasi neleri değiştirecek?" Hurriyet, March 28, 2015. http://www.hurriyet.com.tr/ ic-guvenlik-yasasi-neleri-degistirecek-28579002.

115. For details, see Amnesty International, "Adding Injustice to Injury."

116. Needless to say, this outcome 'requires a level of opposition mobilization, unity, skill, and heroism far beyond what would normally be required for victory in a democracy.' Diamond, "Thinking about Hybrid Regimes," 168.

117. For an analysis of the June 2015 elections, see Canyas et al., "Turkey's 2015 Parliamentary Elections."

118. Kalaycioglu, "Turkish Popular Presidential Elections."

119. Sinan Ciddi, "The End of Turkey's Experiment with Democracy." Huffington Post, November 16, 2015. http://www.huffingtonpost.com/sinan-ciddi/the-end-of-turkeys-experiment-withdemocracy_b_8575748.html.

120. "Turkish Election Campaign Unfair, say International Monitors." Guardian, November 2, 2015. http://www.theguardian.com/world/2015/nov/02/turkeys-elections-campaign-unfair-sayinternational-monitors.

121. "Joint Mission finds Turkish Journalists under Severe Pressure." Committee to Protect Journalists, October 22, 2015. https://cpj.org/blog/2015/10/joint-mission-finds-turkish-journalists-underseve.php.

122. "On Post-election State Violence in Turkey." September 11, 2015. http://www.jadaliyya.com/ pages/index/22620/on-post-election-state-violence-in-turkey.

123. "Deep Divisions in Turkey as Election Nears." Pew Research Center, October 15, 2015. http:// www.pewglobal.org/2015/10/15/deep-divisions-in-turkey-as-election-nears/.

124. Kemal Kirisci, "Is Civil War coming to Turkey?" http://www.brookings.edu/blogs/order-fromchaos/posts/2015/09/23-is-turkey-civil-war-coming-kirisci-ekim?cid=00900015020149101 US0001-0925.

125. “Nokta dergisine polis baskını."BBC Turkce, September 14, 2015. http://www.bbc.com/turkce/ haberler/2015/09/150914_nokta_dergisi. Just four days before the crucial parliamentary election, government trustees were sent in to the pro-Gulen Koza Ipek group - including its media outlets - with the purpose of replacing its senior management. Amnesty International, "Turkey"; "Caretakers take over two Gülen-linked Dailies after TV Channels." Hurriyet Daily News, October 29, 2015. http://www.hurriyetdailynews.com/caretakers-take-over-two-gulen-linkeddailies-after-tv-channels-.aspx?pagelD=238\&nID=90483\&NewsCatID=341; and "Court seizes Control of Gülen-linked Industry, Media Group." Hurriyet Daily News, October 27, 2015. http:// www.hurriyetdailynews.com/court-seizes-control-of-gulen-linked-industry-media-group. aspx?PagelD=238\&NID=90372\&NewsCat ID=509.

126. "Gezici Araştırma'nın anketörlerine gözaltı." Cumhuriyet, September 19, 2015, http://www. cumhuriyet.com.tr/haber/turkiye/372763/Gezici_Arastirma_nin_anketorlerine_gozalti.html\#.

127. "AKP'li Şahin ve Yılmaz'dan halka tehdit." Gercekgundem, October 26, 2015. http://www. gercekgundem.com/siyaset/164147/akpli-sahin-ve-yilmazdan-halka-tehdit.

128. "TBMM Başkanı İsmet Yılmaz: 'Koalisyona muhtaç ederseniz, iş bulmak zor olur.' Hurriyet, October 26, 2015. http://www.hurriyet.com.tr/koalisyona-muhtac-ederseniz-is-bulmak-zorolur-40006382.

129. "Davutoğlu'ndan Van'da tehdit gibi sözler: Beyaz toroslar dolaşacak." Cumhuriyet, October 20, 2015. http://www.cumhuriyet.com.tr/haber/siyaset/391353/Davutoglu_ndan_Van_da_ tehdit_gibi_sozler_Beyaz_toroslar_dolasacak.html\#. 


\section{Bibliography}

Aktürk, Şener. Regimes of Ethnicity and Nationhood in Germany, Russia, and Turkey. Cambridge: Cambridge University Press, 2012.

Amnesty International. "Adding Injustice to Injury." Press release, June 2014. https://www.amnesty.org/ en/press-releases/2014/06/adding-injustice-injury-one-year-after-gezi-park-protests/.

Amnesty International. "Turkey: Pre-election Takeover of Opposition Media Outlets a Major Blow to Freedom of Expression." October 28, 2015. https://www.amnesty.org/en/documents/ eur44/2764/2015/en/.

Arsan, Esra. "Sivil Itaatsizlik Bağlamında Bir Araştırma: Gazeteci Gözüyle Sansür ve Otosansür". Cogito Sivil İtaatsizlik Sayısı: Istanbul, YKY, 2011.

Ayan Musil, Pelin. "Emergence of a Dominant Party System after Multipartyism: Theoretical Implications from the Case of the AKP in Turkey." South European Society and Politics 20, no. 1 (2015): 71-92.

Aydınlı, Ersel. "Turkey under the AKP: Civil-Military Relations Transformed." Journal of Democracy 23, no. 1 (2012): 100-108.

Başkan Canyaş, Filiz, F. Orkunt Canyaş, and Selin Bengi Gümrükçü. "Turkey's 2015 Parliamentary Elections." Journal of Balkan and Near Eastern Studies (2015): 1-13. doi:10.1080/19448953.2015.1 094274.

Carothers, Thomas. "The End of the Transition Paradigm." Journal of Democracy 13, no. 1 (2002): 5-21.

Çarkoğlu, Ali, and Binnaz Toprak. Religion, Society and Politics in a Changing Turkey. Istanbul:TESEV, 2007.

Çınar, Kursat. "Local Determinants of an Emerging Electoral Hegemony: The Case of Justice and Development Party (AKP) in Turkey." Democratization (2015): 1-23. doi:10.1080/13510347.2015.1 077228.

Çınar, Menderes, and Çagkan Sayın. "Reproducing the Paradigm of Democracy in Turkey: Parochial Democratization in the Decade of Justice and Development Party." Turkish Studies 15, no. 3 (2014): 365-385.

Corke, Susan, Andrew Finkel, David J. Kramer, Carla Anne Robbins, and Nate Schenkkan. Democracy in Crisis: Corruption, Power and Media. Washington, DC: Freedom House, 2014. https://freedomhouse. org/sites/default/files/Turkey\%20Report\%20-\%202-3-14.pdf.

Dağıstanlı, Mustafa Alp. 5N1Kim. Istanbul: Postaci Yayin Evi, 2014.

Dahl, Robert Alan. Polyarchy: Participation and Opposition. New Haven, CT: Yale University Press, 1973.

Diamond, Larry. "Thinking about Hybrid Regimes." Journal of Democracy 13, no. 2 (2002): 21-35.

Diamond, Larry. “Facing up to the Democratic Recession." Journal of Democracy 26, no. 1 (2015): 141-155.

Doğan, Pınar, and Dani Rodrik. Yargı. "A Harvard Economist. A Coup Plot. A Career forever Changed." Chronicle of Higher Education. October 16, 2015. http://chronicle.com/article/An-Economist-Turns-SI euth/233802/?key=6PNe2NR2AVSJtgrTcdXjn43Ef8Xg-NEaCsi7SFjt40VwNIhtRi1SWGxRalhKQzBSN0 RyREIORWZqbHJIdXV5TUp3YU9feWtVQy1N.

Doğan, Pınar, and Dani Rodrik. Yargı, Cemaat ve Bir Darbe Kurgusunun İ̧yüzü. Istanbul: Destek Yayinevi, 2014.

European Commission. "Turkey 2009 Progress Report." 2009. http://ec.europa.eu/enlargement/pdf/ key_documents/2009/tr_rapport_2009_en.pdf.

European Commission. "Turkey 2010 Progress Report." 2010. http://ec.europa.eu/enlargement/pdf/ key_documents/2010/package/tr_rapport_2010_en.pdf.

European Commission. “Turkey 2011 Progress Report.” 2011. http://ec.europa.eu/enlargement/pdf/ key_documents/2011/package/tr_rapport_2011_en.pdf.

Freedom House. Freedom in the World Country Reports: Turkey, 1998-2015. http://www.freedomhouse. org/.

Gumuscu, Sebnem. "The Emerging Predominant Party System in Turkey." Government and Opposition 48, no. 2 (2013): 223-244.

Gumuscu, Sebnem, and Deniz Sert. “The March 2009 Local Elections and the Inconsistent Democratic Transformation of the AKP Party in Turkey." Middle East Critique 19, no. 1 (2010): 55-70.

Gürsoy, Yaprak. "The Changing Role of the Military in Turkish Politics: Democratization through Coup Plots?" Democratization 19, no. 4 (2012): 735-760. 
Human Rights Watch (HRW). Turkey's Human Rights Rollback. New York: HRW, 2014. https://www.hrw. org/report/2014/09/29/turkeys-human-rights-rollback/recommendations-reform.

Kalaycıoğlu, Ersin. "Kulturkampf in Turkey: The Constitutional Referendum of 12 September 2010." South European Society and Politics 17, no. 1 (2012): 1-22.

Kalaycıoğlu, Ersin. "Turkish Popular Presidential Elections: Deepening Legitimacy Issues and Looming Regime Change." South European Society and Politics 20, no. 3 (2015): 1-23.

Kınıkoğlu, Batu. "Evaluating the Regulation of Access to Online Content in Turkey in the Context of Freedom of Speech." Journal of International Commercial Law and Technology. 9, no. 1 (2014): 36-55.

Kurban, Dilek, and Ceren Sözeri. Caught in the Wheels of Power: The Political, Legal and Economic Constraints on Independent Media and Freedom of the Press in Turkey. Istanbul: TESEV, 2012.

Kuru, Ahmet T. "The Rise and Fall of Military Tutelage in Turkey: Fears of Islamism, Kurdism, and Communism." Insight Turkey 14, no. 2 (2012): 37-57.

Lancaster, Caroline. "The Iron Law of Erdogan: The Decay from Intra-party Democracy to Personalistic Rule." Third World Quarterly 35, no. 9 (2014): 1672-1690.

Levitsky, Steven, and Lucan Way. "The Rise of Competitive Authoritarianism." Journal of Democracy 13, no. 2 (2002): 51-65.

Levitsky, Steven, and Lucan A. Way. Competitive Authoritarianism: Hybrid Regimes after the Cold War. Cambridge: Cambridge University Press, 2010.

Levitsky, Steven, and Lucan A. Way. "Why Democracy needs a Level Playing Field." Journal of Democracy 21, no. 1 (2010): 57-68.

McCargo, Duncan, and Ayşe Zarakol. "Turkey and Thailand: Unlikely Twins." Journal of Democracy 23, no. 3 (2012): 71-79.

Müftüler-Baç, Meltem, and E. Fuat Keyman. "The Era of Dominant-party Politics." Journal of Democracy 23, no. 1 (2012): 85-99.

O’Donnell, Guillermo A. “Delegative Democracy." Journal of Democracy 5, no. 1 (1994): 55-69.

Öniş, Ziya. "Sharing Power: Turkey's Democratization Challenge in the Age of the AKP Hegemony." Insight Turkey 15, no. 2 (2013): 103-122.

Öniş, Ziya. "Monopolising the Centre: The AKP and the Uncertain Path of Turkish Democracy." International Spectator 50, no. 2 (2015): 22-41.

Özbudun, Ergun. "AKP at the Crossroads: Erdoğan's Majoritarian Drift." South European Society and Politics 19, no. 2 (2014): 155-167.

Özbudun, Ergun. "Turkey's Judiciary and the Drift toward Competitive Authoritarianism." International Spectator 50, no. 2 (2015): 42-55.

Satana, Nil S. "Transformation of the Turkish Military and the Path to Democracy." Armed Forces \& Society 34, no. 3 (2008): 357-388.

Sarıgıl, Zeki. "Civil-Military Relations beyond Dichotomy: With Special Reference to Turkey." Turkish Studies 12, no. 2 (2011): 265-278.

Schedler, Andreas, ed. Electoral Authoritarianism: The Dynamics of Unfree Competition. Boulder, CO: Lynne Rienner Publishers, 2006.

Söyler, Mehtap. "Informal Institutions, Forms of State and Democracy: The Turkish Deep State." Democratization 20, no. 2 (2013): 310-334.

Taş, Hakkı. "Turkey - From Tutelary to Delegative Democracy." Third World Quarterly 36, no. 4 (2015): 776-791.

Taşkın, Yüksel. "Hegemonizing Conservative Democracy and the Problems of Democratization in Turkey: Conservatism without Democrats?" Turkish Studies 14, no. 2 (2013): 292-310.

Tol, Gonul, and Emma Hjerno. "Turkey's General Elections 2015: High Stakes at Home and Abroad." Middle East Institute, 2015. http://www.mei.edu/content/article/turkey\%E2\%80\%99s-generalelections-2015-high-stakes-home-and-abroad.

Turam, Berna. Between Islam and the State: The Politics of Engagement. Stanford, CA: Stanford University Press, 2007.

Turam, Berna. "Are Rights and Liberties Safe?" Journal of Democracy 23, no. 1 (2012): 109-118.

Wigell, Mikael. "Mapping 'Hybrid Regimes': Regime Types and Concepts in Comparative Politics." Democratization 15, no. 2 (2008): 230-250. 
Yardımcı-Geyikci, Şebnem. "Gezi Park Protests in Turkey: A Party Politics View." Political Quarterly 85, no. 4 (2014): 445-453.

Zarakol, Ayşe. "Revisiting Second Image Reversed: Lessons from Turkey and Thailand." International Studies Quarterly 57.1 (2013): 150-162. 